\title{
Territorial embeddedness of natural resource management: A perspective through the implementation of Industrial Ecology
}

\author{
Juliette Cerceau $^{\mathrm{a}, *}$, Nicolas Mat ${ }^{\mathrm{b}}$, Guillaume Junqua ${ }^{\mathrm{c}}$ \\ ${ }^{\text {a } U n i v e r s i t e ́ ~ G r e n o b l e ~ A l p e s, ~} 14$ Avenue Marie Reynoard, 38100 Grenoble, France \\ b PIICTO Association, France \\ ${ }^{\mathrm{c}}$ Ecole des mines d'Alès, 6, avenue de Clavières, 303019 Ales Cedex, France
}

\section{A B S T R A C T}

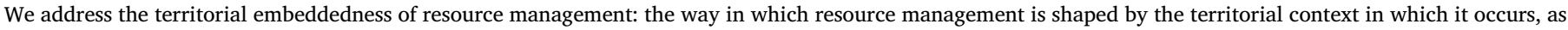

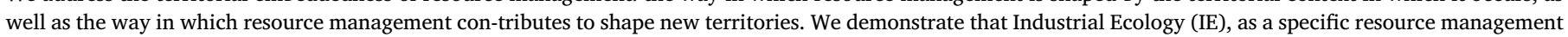

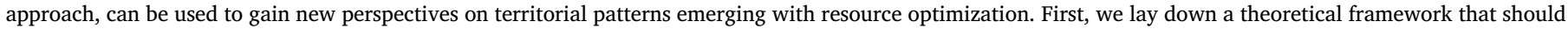

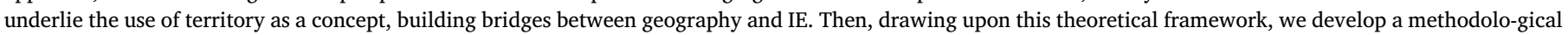

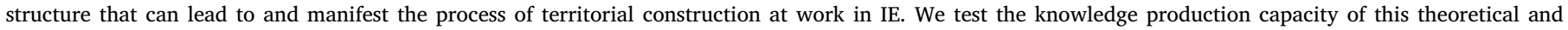

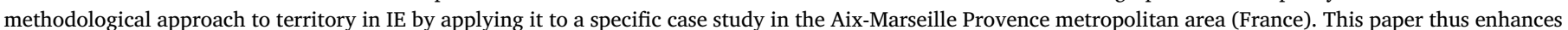

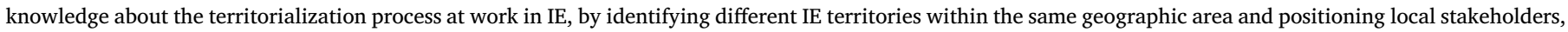

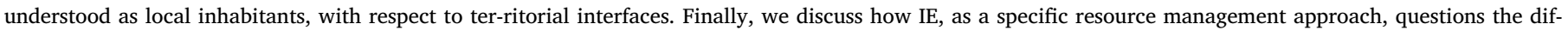
ferent aspects of the connection between people and geographical places in a natural management context.

\author{
Keywords: \\ Territory \\ Territorialization \\ Territorial embeddedness \\ Industrial ecology \\ Industrial symbiosis \\ Metropolis
}

\section{Introduction}

Territorial strategy and resource management are deeply connected. On a global scale, spatial strategies and multi-actor territorial practices for conservation and development reconfigure resource access, control and management, shaping the human-environment dynamics (Bassett and Gautier, 2014). Rassmussen and Lund (2018) observed that new patterns of resource exploration, extraction, and commodification create also new territories. Resource scarcity blurs administrative frontiers and existing political and social orders, whereas the territorialization of resource management creates new orders. On a local scale, resource management issues are definitely bounded by a geographical space that foster the emergence of community-based collaborative partnerships among individuals with different, if not opposing perspectives (Cheng et al., 2003).

In this article, we address the territorial embeddedness of resource management: the way in which resource management is shaped by the territorial context in which it occurs, as well as the way in which resource management contribute to shape new territories. However, the connections between territory and resource management appear difficult to define uniformly since they are deeply context-dependent, varying across spaces and over time, depending on strategies of resource optimization.

To enhance knowledge about territorial embeddedness of natural resource management, we explore the territorialization processes engendered by a specific natural resource management approach, the implementation of Industrial Ecology (IE). IE seeks to optimize resource management by developing interactions between various stakeholders occupying a common geographic area. The core of IE is understanding the structure and functioning of the industrial, urban or societal metabolism through Material Flow Analysis (MFA) that quantifies inputs, outputs, and stocks for a given system (Brigezu and Moriguchi, 2002). Industrial symbiosis, as a way to implement IE, has been defined as engaging traditionally separate industries in a collective approach to gain competitive advantage through the physical exchange of materials, energy, water and by-products. Physical exchanges can occur within a facility, firm, or organization; between firms co-located in a defined eco-industrial park; between local firms that are not located in the same park; and between firms organized "virtually" across a broader region (Chertow, 2000). We argue that IE can be used to gain new perspectives

\footnotetext{
* Corresponding author.

E-mail addresses: Juliette.cerceau@gmail.com (J. Cerceau), Nicolas.mat.eit@gmail.com (N. Mat), Guillaume.junqua@mines-alèes.fr (G. Junqua).
} 
on territorial patterns emerging with resource optimization. For Chertow (2000), the key to industrial symbiosis are collaboration and the synergistic possibilities offered by geographic proximity. For Beaurain and Brullot (2011), as long as IE fosters material or immaterial interactions among stakeholders within a common spatial area, IE should be consider as a local planning strategy. Through resource optimization, IE contributes to the building of a productive territory aiming at reinforcing the sustainability of production processes.

Firstly, we lay down a theoretical framework that should underlie the use of territory, as a concept, building bridges between geography and IE. Secondly, drawing upon this theoretical framework, we develop a methodological structure that can lead to and manifest the process of territorial construction at work in resource management, and IE in particular. Thirdly, we test the knowledge production capacity of this theoretical and methodological approach to territory in IE by applying it to a specific case study in the South of France: the territorialization of IE in the Aix-Marseille Provence metropolitan area. We finally put our conclusions in perspective with the territorial embeddedness of resource management.

\section{Theoretical framework: territories in IE}

Territory is not a stand-alone issue for the IE scientific community. For most of the IE scientific community, geographic issues are reduced to the question of system boundaries (O'Rourke et al., 1996; Spiegelman, 2003; Baas and Boons, 2004). Eco-Industrial Parks, involving geographic concentrations of firms and synergies between facilities, constitute a deliberate attempt to apply the principle of IE in a specific and closed location (Gibbs and Deutz, 2005). Once the system boundaries are set, it becomes difficult to observe what happens beyond the system. However, resource issues cross boundaries: for Bergmann and Holmberg (2016), globalization links human consumption to distant land use mediated by commodity chains and capital. Newell and Vos (2011) highlight the challenges of calculating a local carbon footprint while the complexity of scale is largely a function of the number of actors and geographies involved in globalized commodity and energy networks. At local scale, Guibrunet et al. (2017) demonstrate how waste flows trespass both institutional and geographical boundaries, resulting in interconnected layers of urban infrastructure, services and land use. Cerceau et al. (2014) question the notion of proximity in IE, suggesting that it must be adapted by considering the degree of natural, logistical and infrastructural connectivity between nodes of the IE network. IE would thus take place in "regions" considered as a series of open, discontinuous spaces consisting of the social and physical interactions which stretch across them (Allen and Cochrane, 2007). Do these observations suggest that IE implementation contributes to build territory as the effect of networked relations (Painter, 2008)? Are these relations physical, economic, social, or natural? Do they contribute to shape new territories for local actors? Indeed, these discussions on IE system boundaries and proximity hide the urgent need for a conceptual debate on the underlying definition of territory in IE. It appears necessary to challenge the conceptualization of the territorial system in IE, examining territorialization processes engendered by resource exchanges.

This conceptual debate meets political issues. Beyond the material and physical issues linked with the implementation of industrial symbioses, IE is now being discussed as a political issue linked with economic development, resource management, and land planning. IE, as a public policy, is no exception to the general European movement toward a territorialization of public action (Faure, 2012). In IE, this trend has been crystallized in the exponential, systematic use of a territorial semantic: IE is considered as a "collective territorial action" addressing issues of "territorial governance" (Brullot et al., 2014). It is understood as a "process of territorial development" (Beaurain and Brullot, 2011), as a factor of "territorial competitiveness" through the integration of "territorial resources" in industrial processes (Allais et al., 2015). In
France, this shift has been sealed by the semantic evolution from "industrial ecology" to "industrial and territorial ecology". For Brullot et al. (2014), the addition of "territorial" to "industrial ecology" highlights the reference to a plurality of actors, spaces and issues, and assumes the local relevance of implementing IE. We can thus question the capacity of this territorial semantic to act as a self-fulfilling prophecy: does the announcement of the territorialization of IE suffice to give IE a territorial dimension?

Recognizing (implicitly or explicitly) the territorial dimension of IE is a first step toward the territorialization of IE. To go further, this article challenges the conceptualization of territory as a "black box" in IE, looking instead at the territorial building processes embedded in IE implementation. The objective here is to use geography's specific perspective to uncover the hidden territorial building processes embedded in IE literature. We thus hypothesize that some geographical debates on territory can be found in IE's underlying conceptions of territory.

\subsection{Determinist versus non-determinist conceptions}

It is interesting to think about the underlying reasons for the relative neglect of the concept of territory in IE. It may be plausible to suggest that the concept of territory constitutes a source of embarrassment for the IE community as it recalls the painful though seminal debates on the so-called biological analogy. Indeed, Though IE offers an original way of looking at economic activities, based on an analogy between the science of ecology (ecosystems, metabolisms, symbiosis, etc.) and industrial systems, this analogical relationship raises considerable difficulties due to the variety of interpretation it allows (Hess, 2010). In parallel, for Painter (2008) the concept of territory has been uncomfortable for some geographers because of its ill-defined but powerful associations with animal territories in ethology and sociobiology. Any intrusion of sociobiological assumptions within studies on human activities is subject to significant criticism, beginning with suspicions of environmental determinism.

We can establish a parallel with the two opposite understandings of the biological analogy that can be found in the IE literature:

- On the one hand, a determinist approach considering that man is submitted to biological and physical laws: human beings must be considered as one biological species among others. There is no discontinuity or alterity from nature (Bourg, 2001). Close to human ecology, IE is an attempt to apply to interrelations between human beings, a type of analysis previously applied to interrelations of plants and animals (Park, 1936; Boons, 2009). The analogy must then be applied literally (Jensen et al., 2011) and ecological concepts are directly transferred from biological systems to anthropogenic systems. For instance, Ehrenfeld (2000) uses the ecological notions of connectivity, community and cooperation; Korhonen (2001) involves the biological concepts of circularity, diversity and proximity. Finally, if anthropogenic systems follow the same rules as biological systems, IE cannot be ordered but occurs spontaneously (Chertow, 2000) during the processes of complexification inherent to the evolution of anthropogenic systems.

- On the other hand, a non-determinist approach considering that man is fundamentally different and disconnected from other biological species. Bey $(2001,2005)$ makes a list of these fundamental differences; no natural equivalence for productive labor, incapacity of anthropogenic systems to recycle waste totally, no natural use of fossil fuel energy, etc. For Isenmann (2003), this philosophical bias implies that human beings impose their rules upon nature: man creates the laws of change and permanence (Ehrenfeld, 2003). Hess (2010) alerted the IE community on the dangers of taking the biological metaphor for a model. McManus and Gibbs (2008) highlighted how IE tropes (i.e. turns of phrase used to embellish an expression) introduce significant bias in the way we understand the world. Therefore, the notion of ecosystem is an analogy that should 
not be taken literally (Erkman, 2004). It should be considered as a revelatory metaphor, but must not be used in a context of justification (Isenmann, 2003) or implementation of industrial "ecosystems" (Bey, 2005).

\subsection{Technical versus social conceptions}

The concept of territory also questions the place of the social, cultural and affective dimensions in the territorialization of resource management. Antonsich (2010) retraces the emergence of modern territory until the crossroads between measuring and calculating territory (Elden, 2007, 2010) and 'peopling' territory produced by specific practices and meanings (Di Meo and Buleon, 2005, 2008; Debarbieux, 2009). The concept of territory reveals another source of embarrassment for the IE community as it also revives contrasts between:

- On the one hand, a technical conception focusing on engineering issues raised by flow transfers and loops (Frosch and Gallopoulos, 1989; Allenby, 1992) which favors measuring and calculating approaches focused on the analysis of material and energy flows generated by manufacturing processes. Its methodological developments focus on analytic tools mainly based on the analysis of material and energy flows (Brunner and Rechberger, 2004; Loiseau et al., 2012), among which we can distinguish analytical material flow methodologies (Eurostat, 2001; Hammer et al., 2003), substance flow analysis (Udo de Haes et al., 1997; van der Voet et al., 1999), or input/output tables (Finnveden and Moberg, 2005) used separately or together depending on the objectives, the boundaries of the study, and the availability of data.

- On the other hand, a human conception exploring the "social embeddedness of IE" (Boons and Howard-Grenville, 2009): several authors (Boons and Baas, 1997; Erhenfeld, 2004; Ashton and Bain, 2012) have shown that the implementation of an IE approach depends not only on technical and economic criteria. It also depends on human factors such as trust (Erhenfeld, 2004), the density of relationships (Ashton and Bain, 2012), or the level of coordination between the actors involved in these procedures (Boons and Baas, 1997). Such a comprehensive approach describes the system of representations of environmental and socioeconomic issues that legitimates the implementation of industrial symbioses (Panyathanakun et al., 2012; Cerceau et al., 2012; Brullot et al., 2014)

\subsection{Geographical dimensions in IE}

These multiple, albeit complementary, conceptions of IE lead to a polysemous definition of its geographical dimension (Table 1). The determinist conception of resource optimization in IE addresses geographical space as a "milieu" (Filleron and Viala, 2013). This "milieu" is transformed and transforms human activities, following adaptation, interaction and retroaction processes that can be observed in biological systems. The geographical space, a city for example, is considered as a complete ecosystem (Golubiewski, 2012). Urban metabolism is the analytic approach used to calculate and model the circulation of material and energy flows interconnecting human activities and their milieu defining the urban ecosystem (Rudolf, 2008). The geographical dimension emerges from a network of interactions among human activities and between human activities and their milieu. It is mainly defined as a "space for the circulation of flows" (Sofies, 2011). It imposes limits and constraints on human activity and contributes to define, by regulation, the spectrum of resource optimization processes to be implemented - and among them, industrial symbioses (Isenmann, 2003).

The non-determinist conception of IE addresses geographic space through a relation based on property or power. From a technical point of view, the geographic space is considered as a "basin" (Inddigo, 2012) delimited for a given use in terms of resource optimization. It has much to do with Elden's (2010) definition of "land" in which pieces of spatial organization, including resource locations, are viewed as commodities to be bought, sold or exchange on a market place. From a human point of view, the geographic space is discovered and revealed by the modes of coordination between the actors involved locally (Brullot, 2009). It is defined through a "regionalized system of actors" in physical, organizational, and/or institutional proximity (Buclet 2011; Beaurain and Brullot, 2011). It can embrace, to a certain extent, Elden's (2010) definition of "terrain" emerging from politico-strategic relations to an area, where power encompasses physical and social interactions.

However, neither "land" nor "terrain" nor "milieu" is sufficient for understanding territory (Elden, 2010; Antonsich, 2010). At best, IE adopts a multidisciplinary approach (Baumann, 2009; Golubiewski, 2012) where technical and human conceptions of IE are applied to a common case study (Schalchli, 2011). Political Industrial Ecology definitely opens up a new pathway. Cousins and Newell (2015) have recently demonstrated the interest of linking IE, political ecology and resource geography in order to move toward an expanded approach to societal metabolism that, in particular, incorporates spatiality. PoliticalIE is presented as a means to examine the material impacts of the flow of resources as well as how these flows are shaped and transformed by power, politics, and human practices (Cousin, 2017). Nonetheless, we regret that these recent developments do not explicitly addresses the definition of territory. IE, in its current state of development, offers only a fragmented, juxtaposed, and truncated approach to the object of territory. If IE purports to encompass territory as an object of study, it needs to consider the concept as an integral whole.

\subsection{IE as a process of territorial emergence}

A first step toward a territorialization of industrial ecology consists in adopting an integrative definition of territory that enables to emerge from the impasses underlying the geographical approaches of IE opposing determinist and non-determinist conceptions, on the one hand, and technical/physical, and human/social conceptions, on the other

Table 1

Uncovering hidden geographical dimensions in IE.

\begin{tabular}{|c|c|c|}
\hline & Technical conception & Human conception \\
\hline & - Methodological approach: analytical & - Methodological approach: comprehensive \\
\hline Non-determinist conception & "Land" & “Terrain” \\
\hline $\begin{array}{l}\text { - Philosophical posture: man transcends nature } \\
\text { - Epistemological posture: analogy as a metaphor }\end{array}$ & $\begin{array}{l}\text { A political-economic relation to space considered as a } \\
\text { resource }\end{array}$ & $\begin{array}{l}\text { A political-strategic relation to space considered as a source } \\
\text { of power }\end{array}$ \\
\hline Determinist conception & "Natural milieu" & "Social milieu" \\
\hline $\begin{array}{l}\text { - Philosophical posture: man does not transcend } \\
\text { nature } \\
\text { - Epistemological posture: analogy as a model }\end{array}$ & A physico-material relation to space considered as limit & A socio-ideal relation to space considered as a constraint \\
\hline
\end{tabular}


hand.

In order to go through the determinist/non-determinist impasse, IE have much to gain by adopting the theory of emergence. According to emergentists, as systems acquire increasingly higher degree of complexity, they begin to exhibit new properties that transcend the properties of their constituent parts and behave in ways that cannot be predicted on the basis of the laws governing simpler systems (Kim, 1999). Emergence is characterized by the radical novelty of the whole. It does not contradict determinist laws but leaves space to contingence, luck and thus human free will. For Berque (2010), determining conditions exist at the beginning. But, on the basis of this determined context, human choices combine and accumulate participating to human free will and contingence. Corning (2002) establishes a link between emergence and synergies: novel properties emerge from cooperation producing synergistic effects. As a resource management approach, IE's conceptions of geographical space are fundamentally based on the relation (whether of physical, economic or political nature) between human beings and their environment. In IE, territory can thus emerge from the complex and synergistic interactions within a socio-ecological system. And indeed, since the 1980s, social geographers have used the concept of territory in order to understand the interactions occurring between human societies and their environment: territory is outlined by the eco-bio-sociologic relationships occurring between anthroposystems and ecosystems (Raffestin, 1989).

The emergentist approach allows to reconsider the epistemological function of the biological analogy. If human societies do not transcend the determinist laws of the biosphere, bridges canbe built with the ethological meaning of territory, understood as the results of the interactions of living beings - and among them, human beings - with their environment. We therefore analyze territory as a socioecological system (Redman et al., 2004; Haberl et al., 2006). Socio-ecological interactions appear as a dynamic process in which self-organized subsystems interact. Each subsystem evolves relatively autonomously but interacts with others produce results on the scale of a social-ecological complex (Ostrom, 2009). In that sense, we refer to Di Meo and Buleon (2005)'s conception of territory as "practices-representations of space". This opens way out of the technical/physical versus human/social debates among the IE community. Territory is defined as dynamic and spatialized practical and symbolic forms designed by human physical and cognitive activities (Di Méo, 2008). It can only emerge through both the physical-factual relationship with an ecological environment and a symbolic-sensitive relationship with a social landscape (Berque, 2000). By stating that the territory is manifested in the relationship between an actor and the environment, we mean that not it cannot be designated as a phenomenon in any other way (Vattimo, 1985; Heidegger, 1986, Hoyaux, 2000).

Fundamentally, the biological analogy, as the epistemological funding of IE, must be considered as a translation process (Callon et al., 2011) that transposes and translates ecological principles from biological to anthropogenic systems and thus reconfigures the socio-ecological systems (Isenmann, 2003), contributing to the emergence of novel properties, and of territory in particular. We thus assume that IE, as a descriptive and prescriptive science, participates in the representation and structuring of a geographic space as a territory (Fig. 1).

It participates in defining territory as it assumes specific interactions of local actors with a geographic space, making it necessary to deal and interact with the territorial circulation of flows and with the material and symbolic forms that they perceive (Debarbieux, 2009). This geographic definition of territoriality echoes ethology, for which territoriality refers to the interactions of individuals of the same species with a space where they know all the possibilities and resources better than the neighbors (Ruwet, 2013). Beyond this descriptive approach, this interactive definition of territory also embodies a prescriptive approach enabling the transformation of the territory: by defining territory, actors make "territory". With Brullot et al. (2012), we assume that IE dynamics institutionalize geographic areas into territories by acting upon them. Symbiotic physical exchanges, knowledge, ideas, and values also interact to drive the territorialization process and a territorial anchorage of IE. As a result, we formulate the hypothesis that IE enables a "territoriality-territorialization process" (Hoyaux, 2002): as actors represent their territory in symbiosis, they organize themselves in order to implement synergies; and, it is through the implementation of synergies, that actors modify the representation they have of their territory.

\section{Methodology: a phenomenological approach to territory in IE}

We shall now present a methodological structure aimed at understanding territory, and its definition and structuration in IE. This methodological structure must enable the manifestation and emergence of a territory in IE. It must put into perspective the system of territorial construction in IE at the level of each actor but also at the scale of a community of actors. It must enable the manifestation and collecting of the expression of territoriality and territorialization. It must promote the emergence of a collective definition of the territory and the implementation of the collective territorial project by and for the implementation of IE within a specific geographic area. It will thus be consistent with an experimental methodological approach (Rossi et al., 1989), based on a qualitative study (Morse, 2008) which aims at highlighting the process of territorial construction in IE. We seek both to describe and cause, to observe and generate the definition and making of territory in IE. Our methodology thus has a double objective: 1/a descriptive objective that aims at defining the individual and collective patterns of interactions between actors and their geographic space; 2 a prescriptive objective that aims at designing a collective territorial project through the prism of IE.

\subsection{Data collection}

We stated that territory is defined through complex actor-space interactions. Therefore, territory must be sought within the process of objectivation (Noucher, 2007) and symbolization that actors develop during such an interaction. We adopt the point of view of phenomenological and hermeneutical geography (Hoyaux, 2000) by working on "stories of space" (De Certeau, 1990) that manifest the way actors think about and build territories in IE. We therefore consider, as relevant intermediary data in the establishment of territory, discourses about the way IE projects condition and are conditioned in a certain actor-space interaction. This approach supposes that actors are considered as phenomenological subjects able to manifest, through representations and actions, their interactions with spaces that constitute and establish territories. As such, we define them as inhabitants: inhabiting, dwelling is manifested both in the act of building and deploying actions through space and in the act of representing and relating this relationship with space (Hoyaux, 2002).

A first methodological step thus consists in defining explicative patterns in order to use them as codes to decrypt the modalities of interactions with the geographic space in IE, as well as to communicate and interact with local actors (Di Méo, 2008). A second step consists in discussing the sampling procedure and its validity. Finally, a semistructured interview guideline has been developed. The application of this methodology on a territory is detailed in Section 2.

\subsubsection{Definition of explicative patterns}

An international review of IE initiatives carried out in coastal areas (Cerceau et al., 2014), on the basis of the analysis of local stakeholders' discourses collected by semi directed interviews and documentation, was used to define territorial patterns according to a spatio-temporal typology, thereby overlapping Di Meo and Buleon (2005) statement that territories are in fact "space-times". The temporal interaction with space in IE has been identified at different prospective levels: 1/as a short-term reaction to a declared urgent situation, 2/as a medium-term 


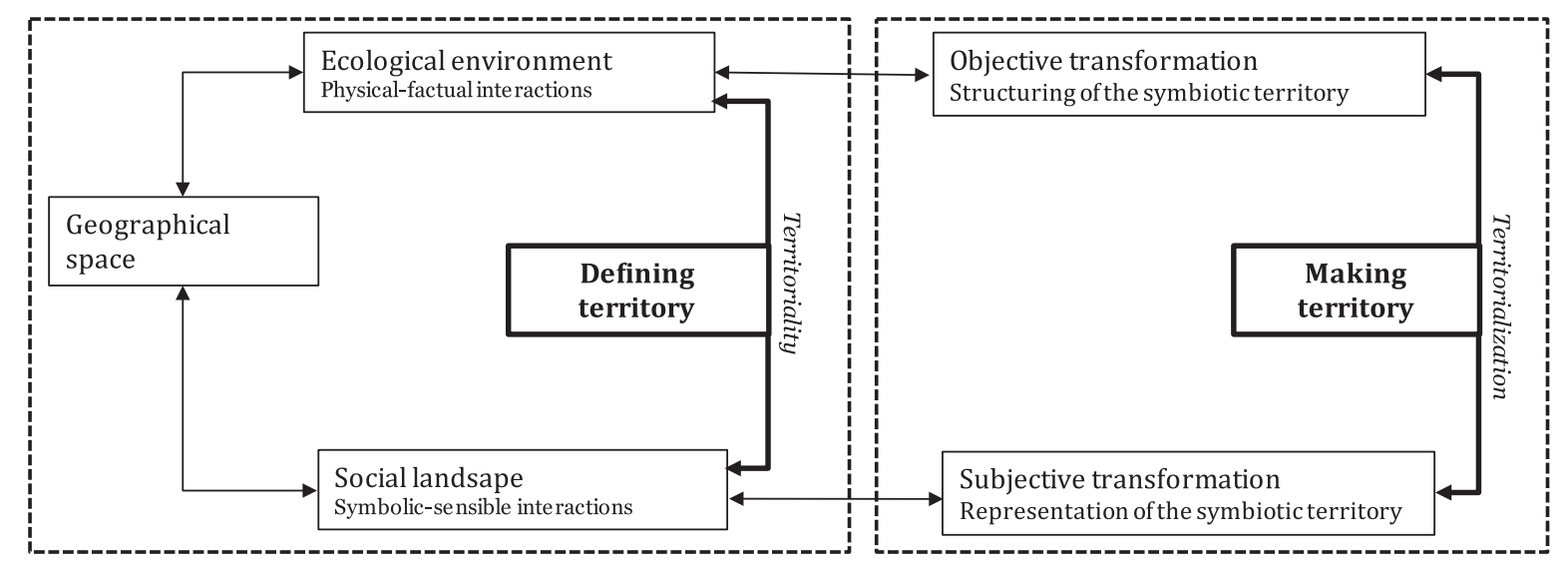

DESCRIPTIVE APPROACH

PRESCRIPTIVE APPROACH

Fig. 1. IE as a process of territorial emergence.

Table 2

Territorial patterns for IE (adapted from Cerceau et al., 2014).

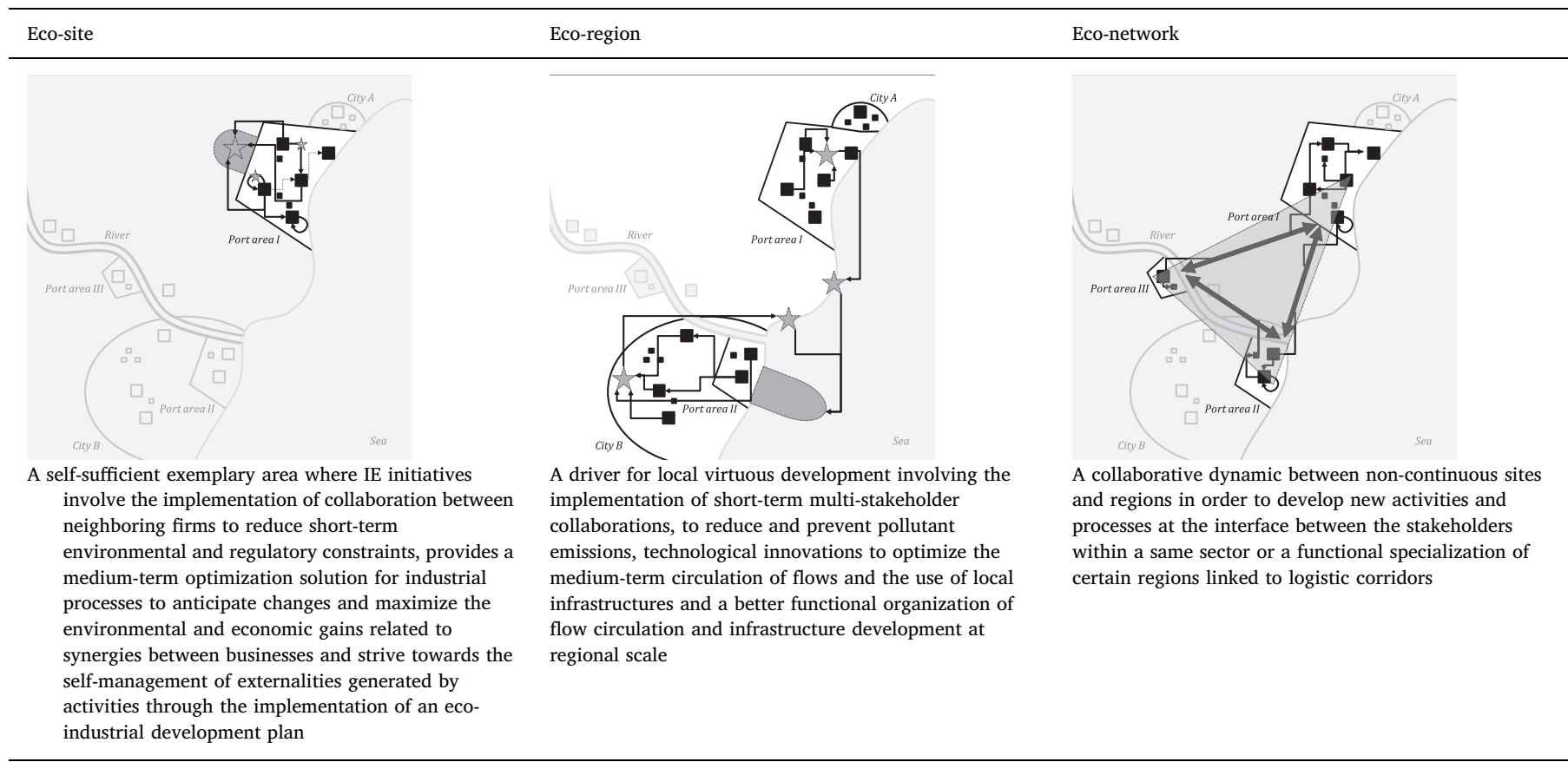

precautionary strategy in response to forecast changes or 3/as longterm ambitions to bring about required changes. The spatial dimension of the interactions varied in scope: 1 /the site, 2 /the city and region, and $3 /$ the network (connected at a national or international scale). By linking the spatial and temporal dimensions, 9 space-ime patterns were identified. In order to conduct our interview, we selected three major spatio-temporal patterns of the actor-space interactions constitutive of territory in IE (Table 2).

\subsubsection{Sampling strategy}

Sampling is always a problematic issue in qualitative research. Saturation, which is usually used as a guiding principle during data collection, determining most qualitative sample sizes, is a rather elastic concept: qualitative samples must be large enough to assure that most of the perceptions are covered, but also precise enough not to become repetitive and superfluous (Mark, 2010). Table 3 details the composition of the sample of local actors interviewed in 2013 and 2015. Following the principle that expertise in the chosen topic can help to reach saturation more quickly (Jette et al., 2003) our sample was made up of local actors identified as "experts" able to understand and restitute the
Table 3

Panel of interviews.

\begin{tabular}{lll}
\hline Types of local actors & $\begin{array}{l}\text { Number of } \\
\text { interviews }\end{array}$ & $\begin{array}{l}\text { Number of local actors } \\
\text { interviewed }\end{array}$ \\
\hline $\begin{array}{l}\text { Local, regional and port authorities } \\
\text { Firms, socioeconomic networks and }\end{array}$ & 9 & 19 \\
$\quad 10$ & 12 \\
$\begin{array}{l}\text { inter-professional syndicates } \\
\text { Retwork actors }\end{array}$ & 7 & 13 \\
Tosearch actors & 7 & 7 \\
\hline
\end{tabular}

process of territory-building through IE projects and dynamics. We sought to include a diverse range of points of view on the phenomenon rather than to be exhaustive concerning the number of local stakeholders involved in IE approaches. To this end, we sampled a range of different actors: $37 \%$ of actors intervened as members of local (local government, urban authorities, chamber of commerce and industry, etc.), departmental (including chambers of agriculture), regional 
(Region, Regional Chamber of Commerce and Industry, etc.), and port authorities. $24 \%$ of interviewed actors were involved in socioeconomic activities (firms, trade unions, business association, etc.). Finally, 25\% were network actors intervening at various scales, and $14 \%$ belonged to the scientific community locally involved in issues of resource management and territorial development. As for the geographic distribution of our sample, $59 \%$ of interviewed actors were involved in organizations that go beyond the metropolitan area (departmental and regional levels in particular), and thus provide a global vision of the integration of the metropolitan area in a broader geographic context. 33\% of the panel intervened at an infra-territorial level, at the scale of an industrial site, an area of activity of a local authority or an employment area. Finally, $8 \%$ of our sample concerned actors whose knowledge and activity corresponded to the administrative limits set by the metropolitan project.

We selected this panel using an iterative logic, advancing by progressive waves of selection (Miles and Huberman, 2003). The two interview campaigns produced a total of 33 interviews, 51 local actors were encountered, $35 \mathrm{~h}$ of discourse were recorded, and 450 pages of "stories of space" were transcribed. With regard to Mark (2010)'s inventories of samples in 506 qualitative studies, with 51 actors interviewed our sample size falls within the range considered as relevant by qualitative researchers.

Our sampling framework was mainly guided by the research question, which addresses the building of territory in IE. Therefore, saturation is not the primary objective of our sampling strategy. We prefer to adopt a pragmatic approach by choosing a sample of interviews that appears sufficient to enable the development of meaningful conclusions and useful interpretation regarding our research question.

\subsubsection{Semi-directed interview}

On the basis of these explicative patterns, interviews were conducted with our panel of local actors using a semi-directive approach (Table 4).

Interviews were transcribed by means of a systematic qualitative note-taking process (Paille, 2004) in order to record both the exchanges and the researcher's observations during the interview.

\subsection{Discourse analysis}

Territory emerges not only from the interaction between the actor and geographic space; it also emerges in interactions between actors. Thus, territory emerges from the synergy of interactions of each actor with the same area. The methodological approach that seeks to bring out a definition of territory and an intended project for that territory in IE needs to open up the dialogue between different "stories of space" (De Certeau, 1990) collected from different actors. In other words, for a single geographic space, there is no single and unique territory a priori, but rather a collection of representations. The stand-alone analysis of each discourse collected results in a polyphonic understanding of the territorial building process in IE: each actor thinks and acts upon the studied geographic area and develops a specific understanding of the territory built through the IE dynamics. The goal was therefore to build, at the interface of these polyphonic representations of territories, a shared vision of a common territory through typological analysis. The discourse analysis was a three-stage process: 1/a typological definition of territory through the intuitive and spontaneous interactions of actors, understood as inhabitants, with a single geographic area; 2/a typological definition of a project for the territory, by the integration of industrial-ecology dynamics in the spatiality and temporality of the territorial development; 3/analysis of the positioning of local actors, in terms of governance, within this common vision of and project for the territory.

\section{Application to Aix Marseille Provence metropolitan area}

\subsection{Description of case study}

Assuming that the territory does not exist by itself but only becomes manifest in the interaction with actors linked to a specific geographic area, and assuming that the researcher, in studying the area, is also part of this manifestation of territory, it is difficult to describe our case study without already initiating the territorial construction process. Nevertheless, in line with the definition of territory as a socioecological system, we give a first reading of our case study, by providing some spatial, temporal, structural, and organizational data about this system.

The scope of this of study is initially defined by the administrative boundaries of the future metropolitan area of Aix-Marseille Provence, in the South of France, covering $3173 \mathrm{~km}^{2}$. Industrial, agricultural, urban, logistic, and natural subsystems are interwoven within this geographic area. The industrial sub-systems focus around the industrial ports (Etang de Berre, Marseille-Fos), major industrial parks (Gardanne, Cadarache, Vitrolles, etc.) and major economic areas (Les Milles, Ahtélia, etc.). The logistics subsystem is built consistently with these industrial zones, based on major port and shipping infrastructures on the coast, and large transit routes irrigating the whole region and nation. The agricultural subsystem is mainly focused in the center and north of the area and covers a total of $760 \mathrm{~km}^{2}$, which represents $24 \%$ of the whole surface area. The urban sub-system is dominated by a conurbation between the two main poles of Aix and Marseille. The natural subsystem covers an area of $1910 \mathrm{~km}^{2}$, or $61 \%$ of the metropolitan area with $180 \mathrm{~km}$ of coastline and a national park (see Fig. 2).

This study covered a period from 2013 to 2015, with two interview campaigns. It fell within a particular organizational context, namely the building of Aix-Marseille-Provence Metropolis, in line with the 2014 French Law on Decentralization and the Reform of Public Action, which fosters the strengthening of identity of French metropolises. It occurred

Table 4

Semi-directive interview guidelines (abstract).

\begin{tabular}{|c|c|}
\hline Space and time descriptors & Questions \\
\hline "Me": defining myself as an "inhabitant" & $\begin{array}{l}\text { Where do you live? Since when? Do you feel a sense of belonging to this territory? Are you involved locally in the development of this } \\
\text { territory? Do you consider it as "your" territory", your home? } \\
\text { What relationship do you have with local resource management? Do you consider yourself as a stakeholder of the local IE dynamics? } \\
\text { How? }\end{array}$ \\
\hline "Here": apprehending space & $\begin{array}{l}\text { How do you define your territory? and its evolution? } \\
\text { In your opinion, what are the main functions of this territory? Are there interactions between port, industry, agriculture, and city? } \\
\text { In your opinion, what is the relevance of the metropolitan scale for the IE?In your opinion, which of these scales (eco-site, eco-region, } \\
\text { eco-network) } \\
\text { best fits territorial dynamics and evolution? And which of these spatial scales best fits with IE dynamics? Why? }\end{array}$ \\
\hline "Now": apprehending time & $\begin{array}{l}\text { We generally distinguish three time frames in terms of land planning: the "short-term", the "medium term," and the "long-term". } \\
\text { Which do you think is the most revealing temporal dynamic for your territory? } \\
\text { In your opinion, which of these temporal best fits IE dynamics? Why? }\end{array}$ \\
\hline
\end{tabular}




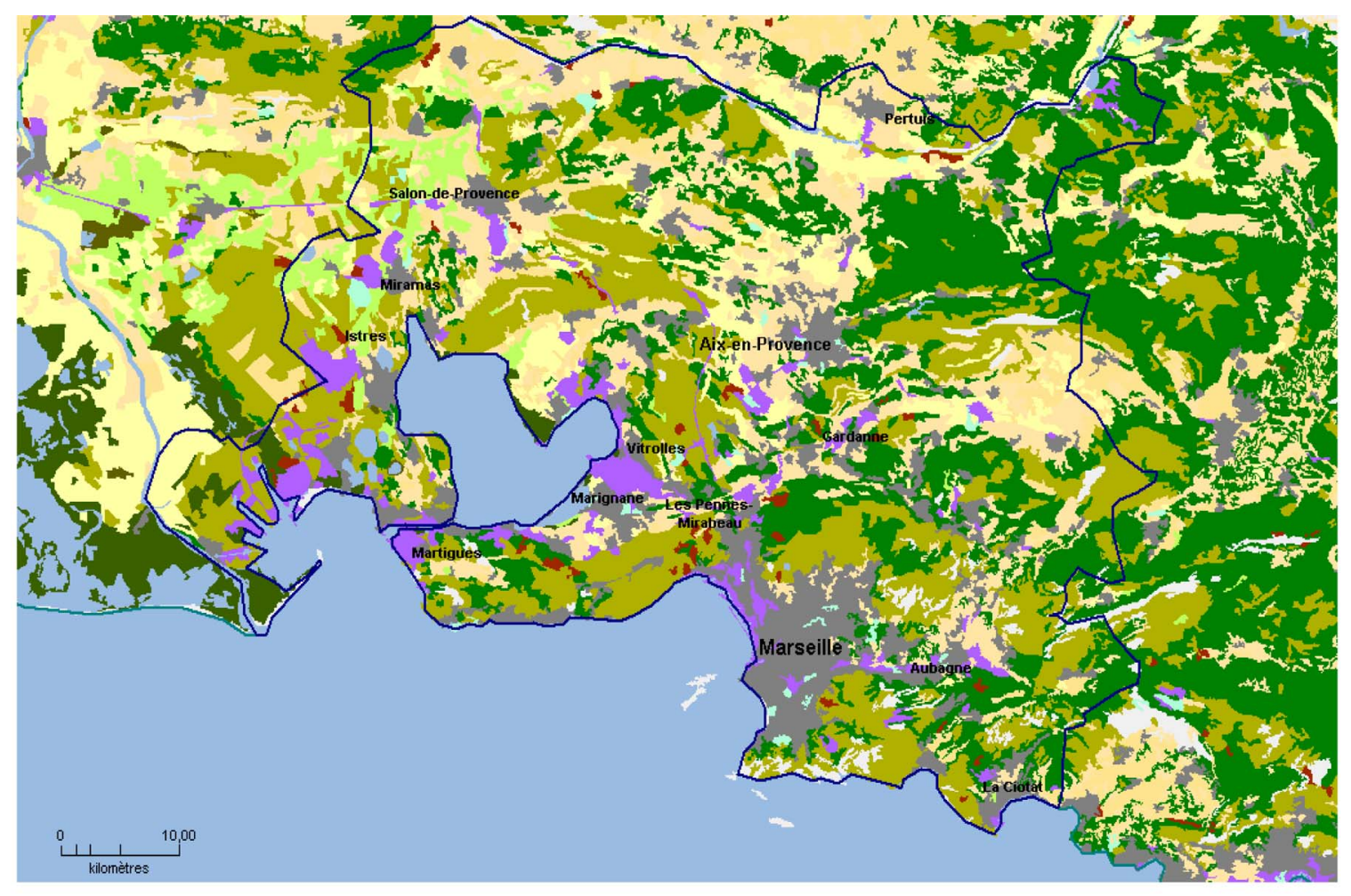

\begin{tabular}{ll}
\hline Land use & Corresponding subsystem \\
\hline & Limits of the metropolitan area \\
\hline $\begin{array}{l}\text { Industrial, commercial areas and communication networks } \\
\text { Mines, landfill }\end{array}$ & Industrial subsystem \\
\hline $\begin{array}{l}\text { Urban areas } \\
\text { Artificialized green area, non agricultural }\end{array}$ & Residential subsystem \\
\hline $\begin{array}{l}\text { Arable land } \\
\text { Permanent cultures } \\
\text { Grasslands } \\
\text { Divers agricultural areas }\end{array}$ & Agricultural subsystem \\
\hline $\begin{array}{l}\text { Forests } \\
\text { Shrub and/or herbaceous vegetation environments } \\
\text { Open areas } \\
\text { Internal wetlands } \\
\text { Maritime wetlands }\end{array}$ & \\
\hline
\end{tabular}

Fig. 2. Land occupation in Aix-Marseille Provence Metropole.

Source: Corine Land Cover, 2006.

completely in a context of the construction of a new metropolitan territory, confirmation of geographic unity and coherence, and the emergence of a new political institution. Among the working groups with local partners led by the Inter-ministerial Mission of Prefiguration for the Future Metropolis, the emphasis was placed on organizing connections between people, between urban and economic centers, between urban and rural areas, through a better synergy among the different territorial functions. Another issue was the strategic positioning of this new political institution and the definition of its addedvalue in relation to already existing stakeholders (local authorities, regional institution, port authority, etc.)

\subsection{Results and discussion}

4.2.1. Polyphonic definitions of actor-space interactions: analyzing actors as inhabitants of the Aix-Marseille-Provence Metropolitan area

The starting point of our analysis is the actor, through his capacity to produce a discourse about his interaction with geographic space and thus to manifest the process of building a territory. We place the actor at the core of the territorial knowledge production process. We stated above that the intuitive and spontaneous interaction to geographic spaces consists in dwelling in them (Hoyaux, 2002). This act of dwelling expresses itself through both discourses and representations of space (symbolic-sensitive interactions) and the interaction of actions and buildings upon space (physic-factual interactions). These insights into individual material and psychological relationships with a geographic 
area can be put in perspective using the concept of sense-of-place, as described by Montgomery (1998), namely as a combination of physical form, meaning and activity.

The act of dwelling, like sense-of-place, is perceived, interpreted, and narrated by inhabitants. It translates in discourse as feelings and emotions about attachment to a place, specific bonds or ties between individuals and a specific place (Hidalgo and Hernandez, 2001). This place attachment can be pointed out in the discourses collected:

"I have many ties... Ties that are linked to the territory, ties with people with whom I worked 15 years ago"1

\section{Or on the contrary,}

"I have no particular anchorage with the metropolitan area"

Among place attachment dimensions, Ujang and Zakaniya (2015) pointed out 1 /sense of belonging and rootedness, 2 /place identity and 3 /place dependence. Indeed, the actors interviewed manifested a strong sense of attachment and belonging based on their geographic place of birth, at different scales:

- At the local scale: "yes, I am a native of Marseille"

- At the regional scale: "I was born in Provence"

- At the Mediterranean scale: "I deeply believe that I am Mediterranean"

And for those who are not native to the geographic area, their place of birth can provide arguments for not developing a strong feeling of belonging to that particular space: "I consider myself at home in all European countries". As a result, discourses on rootedness, on this natural and unmediated bond to place (Arefi, 1999), contribute to defining actors' identity. This place identity, the way in which a place can inform the identity of actors (Ujang and Zakaniya, 2015), can be defined in a symbiotic interaction to the specific area:

"I am a local"

Or, on the contrary, it can be defined in a distanced and even uprooted relationship to space:

"I would be the same on any territory. I uprooted after my studies, I feel good anywhere. I have a visceral attachment to humanity, and everything that contributes to humanity, animals and plants ... but not to territory."

Discourses on the place of birth often go with factual stories of spatial mobility. Some actors, natives of Marseille, relate the path that led them to leave the place and then come back:

"I live in the heart of Marseille, in the 5th district. I came back to Marseille in 1998. [...] But I have lived in Paris, Lille, Lyon ... I had a rough life. I was very mobile."

Others define themselves as outsiders that migrated to Marseille for personal or professional reasons:

"We wanted to settle in the area. We always dreamed of living in the South of France"

"We go where there are career opportunities."

Another aspect of an intuitive, sensitive, and symbolic interaction with space is expressed in terms of knowledge:

"It's a territory that I know very well."

\footnotetext{
${ }^{1}$ From now on, phrases in quotation marks correspond to the translation from French to English of discourses and words collected among local actors during the two interview campaigns of 2013 and 2015. Words in brackets have been added by the authors for better comprehension.
}

This territorial knowledge can counteract the fact of not being a native of the geographic area:

"No, [I'm not a native]. But I have been working for 25 years in Marseille, I have an idea of the territory and of how it works".

Nevertheless, rootedness and mobility do not impact the personal and positive involvement of actors in the territory. This involvement can be that of native actors:

"I was born in Marseille, in the metropolis. I have been living here for 30 years. So, you know, I do not feel like a foreigner, I feel invested in that territory."

It can also be manifested by actors that have recently arrived in the geographic area:

"I feel very well living here, doing something, investing myself. Even though it is sometimes difficult to invest here if you're not a native."

In order to qualify a physical territorial involvement, the actors interviewed were questioned in their capacity as territorial "stakeholders" (Freeman, 1984), namely in their capacity to affect or be affected by territorial development projects. This capacity is expressed by local actors through discourses on their role and function, which can be defined in passive terms:

"I was asked to take on this function. [...] it was proposed to me to take the lead"

Or in active, even proactive terms:

"I took this chair because I wanted to transmit my own values"

"I played the role of catalyst, of coach"

It also goes with discourses on the motivations for acting on territorial development, forces that act upon the actor and explain his/her choices and behavior for fulfilling a goal (Maslow, 1954). Among the discourses collected, we can highlight:

- Belonging, as the motivation to be part of a local community invested in territorial development: "it is to be able to work collectively or otherwise"

- Self-esteem, as the feeling of being useful and valuable: "the issue is to influence, to contribute, at my own level, to territorial development"; "it is the willingness to do something smart for the territory"

- Self-accomplishment, as the development and diffusion of his/her own knowledge and values: "Sustainable development is something you have in your guts. So that's the motivation for my part, working on it"

These insights into territorial involvement can be put into perspective with place-dependence defined as the importance of a place in providing motivations to support and legitimate specific goals and activities (Ujang and Zakaniya, 2015).

Through the two components of the individual relationship with space expressed in discourses, namely 1 /the symbolic-sensitive territorial representations (through the sense of belonging and place identity) and 2/the physical-factual territorial implications, we can distinguish four main categories of inhabitants in the metropolitan area (Table 5):

- Transitory intervenor: the actor defines himself as a foreigner with no particular link with the territory for which he is mandated to participate in territorial development.

- External pathfinder: the actor positions himself as an external coach contributing his/her skills and expertise to support the implementation of territorial development.

- Local stakeholder: the actor involves himself as a local employee within the organization for which he works to implement territorial 


\begin{tabular}{|c|c|c|c|}
\hline & & \multicolumn{2}{|l|}{ Physic-factual territorial implication } \\
\hline & & Commissioned to & Devoted to \\
\hline \multirow[t]{6}{*}{$\begin{array}{l}\text { Symbolic-sensible territorial } \\
\text { representations }\end{array}$} & $\begin{array}{l}\text { No feeling of } \\
\text { belonging }\end{array}$ & $\begin{array}{l}\text { Transitory intervenor } \\
\text { "I am from Brittany"/"I am in charge of..." } \\
\text { "I live in Paris"/"it is previous professional } \\
\text { relationships that explain that I work in Marseille" } \\
\text { "we are mandated to invest in this issue"/"I don't have } \\
\text { any feeling of belonging" }\end{array}$ & $\begin{array}{l}\text { External pathfinder } \\
\text { "I am not a native of this territory"/"sustainable } \\
\text { development, it is something you have in your guts" } \\
\text { "someone from outside"/"I am really involved" }\end{array}$ \\
\hline & Feeling of & Local stakeholder & Local missionary \\
\hline & belonging & $\begin{array}{l}\text { "I was born in Provence, it is a region I really love"/ } \\
\text { "they asked me to take up this job" }\end{array}$ & $\begin{array}{l}\text { "I deeply love this territory"/"beyond belonging, I have } \\
\text { projects". }\end{array}$ \\
\hline & & $\begin{array}{l}\text { "I am from Marseille"/"my role is mainly linked with } \\
\text { my job." }\end{array}$ & $\begin{array}{l}\text { "I have been in this region for } 45 \text { years"/"I want to } \\
\text { transmit my values" }\end{array}$ \\
\hline & & & $\begin{array}{l}\text { "I am strongly anchored in this territory"/"I want to } \\
\text { provide my contribution" }\end{array}$ \\
\hline & & & $\begin{array}{l}\text { "Feeling at home"/"my role is to make actors work } \\
\text { together" }\end{array}$ \\
\hline
\end{tabular}

development.

- Local missionary: driven by a commitment to and strong investment in the territory, the actor is defined as the engine of the emergence of the territorial project.

We can analyze these dwelling patterns through the law of proxemics, according to which the importance of a phenomenon decreases with distance (Schwach, 1998). Proximity can be understood both in symbolic terms, through the affective and cognitive sense of belonging to the territory, and in physical terms, through territorial involvement. In symbolic terms, the use of "I" and "Myself" appears symptomatic: for instance, in discourses the local missionary tends to place, "I" at the core of the process of territory making, as a proof of his/her profound territorial sense of belonging and involvement. Physical proximity can be apprehended through the scale of intervention (Table 6). Among our panel, we distinguished the infra-territorial, metropolitan and supraterritorial scales. At the supra-territorial scale (departmental and regional levels) local stakeholders and missionaries are overrepresented: among the 29 actors of these dwelling patterns, 17 are involved at the departmental, regional or national level. This no longer seems to be a paradox if we consider the fact that most of these supra-national institutions are located in Marseille or Aix, which are the urban centers of gravity of the metropolitan area, explaining the proximity of local actors to metropolitan issues.

Dwelling patterns can also be usefully crossed with the type of actors identified in the panel (Table 7). For instance, local missionaries are over-represented among local, departmental and regional authorities as well as among network actors.

In line with these results, we can specify representative profiles for each dwelling pattern identified in the Aix-Marseille-Provence metropolitan area:

- Transitory intervenor: this actor tends to be part of a supra-territorial

Table 6

Categories of inhabitants and territorial scales of intervention.

\begin{tabular}{|c|c|c|c|c|}
\hline \multirow[t]{2}{*}{ Dwelling patterns } & \multicolumn{4}{|l|}{ Territorial scale } \\
\hline & Infra-territorial & Supra-territorial & Metropolitan & Total \\
\hline External pathfinder & 2 & 3 & 1 & 6 \\
\hline Transitory intervenor & 1 & 6 & & 7 \\
\hline Local stakeholder & 2 & 6 & 1 & 9 \\
\hline Local missionary & 9 & 11 & & 20 \\
\hline No answer & 3 & 4 & 2 & 9 \\
\hline Total & 17 & 30 & 4 & 51 \\
\hline
\end{tabular}

organization, such as a firm whose head office is not necessarily based in the territory, a consulting agency, or a regional network actor.

- External pathfinder: this actor has a dual profile, either 1/that of a research actor who locally transfers knowledge and expertise, or 2/ or that of an industrial manager whose career opportunities led $\mathrm{him} /$ her to invest locally.

- Local stakeholder: this pattern seems to be a prerogative of supraterritorial actors working in companies or departmental and regional authorities, whose strategic project is coherent with local territorial development.

- Local missionary: this pattern is very diverse, which suggests that this is not so much the institution that determines the positioning as an inhabitant, but rather the expression of individuality beyond any organizational affiliation.

Through the discourses collected, the objective is therefore to describe and to structure the metropolitan area as a territory, through the implementation of IE. Questioned on the basis of pre-identified territorial patterns for IE (eco-site, eco-territory and eco-network), the actors interviewed first corroborated the "polyphonic understanding" (Hoyaux, 2000) of the metropolitan territory at work in IE: each actor expressed his own understanding of different territorial patterns and therefore his own definition of the Aix-Marseille-Provence territory in IE. If the actor is the junction point between a geographic space and a project for a territory through IE, we then questioned the role played by dwellers in the definition and making of the territory in IE. Territorial patterns identified and articulated in collected discourses were analyzed with regard to the various types of actors and the different dwelling patterns.

\subsubsection{Territorial mosaic for IE}

Collecting discourses about territorial patterns clarified what these theoretical explicative patterns mean, evoke and imply for local actors. The eco-site pattern seems to be understood relatively unambiguously by the various actors interviewed, through terminologies referring to "sites", "platforms" or "demonstrative areas". They stressed the local ("it is purely local. The perimeter does not exceed the local") and the industrial ("it concerns the industrial part of the metropolis") character of socioeconomic zones. Proximity appears crucial:

"In IE, there is an issue of density in terms of proximity and of affinity in terms of similar or complementary activities."

This discourse manifests both the physical and institutional dimension of proximity: space in IE supposes a short geographic distance as well as a propinquity of stakeholders' rules of actions (Buclet, 2011). 
Table 7

Categories of inhabitants and type of actors

\begin{tabular}{|c|c|c|c|c|c|c|}
\hline \multirow[t]{2}{*}{ Dwelling patterns } & \multicolumn{6}{|l|}{ Type of actors } \\
\hline & Research actor & Network actor & Port authority & Firms & Local, departmental and regional authority & Total \\
\hline External pathfinder & 2 & & & 3 & 1 & 6 \\
\hline Transitory intervenor & 1 & 2 & & 2 & 2 & 7 \\
\hline Local stakeholder & & & 1 & 4 & 4 & 9 \\
\hline Local missionary & 3 & 8 & 1 & 3 & 5 & 20 \\
\hline No answer & 1 & 3 & & & 5 & 9 \\
\hline Total & 7 & 13 & 2 & 12 & 17 & 51 \\
\hline
\end{tabular}

It is understood in terms of "integration" and "synergies" developed between local activities and is thus very close to the eco-industrial park notion (Gibbs and Deutz, 2005). However, this territorial pattern focused on the eco-site is not partitioned and bounded: "we are far from a completely closed system" and it must be understood "within a territorial network", where we must "seek for opportunities beyond the site". The eco-site diffuses beyond the administrative limits of a socioeconomic area, corroborating the fact that resource management does not fit into a decreed system perimeter and cannot be studied looking at the eco-site scale alone (Guibrunet et al., 2017). In an organic metaphor, one interviewed actor describes the eco-site as the heart of IE that can irrigate a larger space: "the heart of IE is located at the site level". The eco-site must "create a chain reaction". It is a "contribution for the development [of IE] at the metropolitan scale".

The eco-region pattern echoes discourses on the multi-polarization of the metropolitan area:

"We have a system that is truly multipolar in the region. So there are initiatives in all parts of the region".

This multi-polarization has many facets: it is administrative through the "institutional fragmentation of the territory"; it is also functional through the dispersal of various industrial, urban, agricultural, logistical components. The terms "connection", "link", "network" and "connectivity" appear repeatedly in collected discourses. The territorialization of IE is therefore intended to enhance the networking between the different poles of the metropolitan area. It aims at developing links between the different functions of the metropolitan area, through the "creation of value chains", "seeking opportunities", and the "setting up of inter-sectoral relationships". As theorized by Allen and Cochrane (2007), the region is formed out of an open and ongoing nexus of relations and connections among discontinuous spaces. The perimeter of this eco-region is not delimited. The administrative limits of the metropolitan area appear as an appropriate perimeter for the implementation of IE:

"For me, the metropolis is truly the key territory for experimentation."

However, the metropolis does not fully epitomize this territorial scale of IE:

"There are plenty of things that go beyond the metropolitan level.

You have to get Toulon, we must seek, why not, Barcelona or Lyon, or other, to reach a good metropolitan project"

Finally, one type of discourse tends to legitimate the eco-network pattern as a relevant territorial scale for the implementation of IE. Interviewed actors first evoke the network of pipelines that historically link the local industrial platforms of Fos, Lavéra and Berre. IE could contribute to opening up this industrial network to other activities through a better socioeconomic networking between activities or sites at the metropolitan scale. The objective would be to create ecosystems of skills or activities, "small cells" or "small solutions which, if multiplied, could actually make sense". This local eco-network first embodies in the exchange of information, skills and expertise from one site to another. Yet some actors also consider localization in a port logistic corridor as a lever for the implementation of IE at a global scale, through the development of flow exchanges at national scale through the Rhone river corridor and at international scale through the major maritime routes. IE could then contribute to a "very concrete and operational internationalization of flow exchanges" opening the local IE network, to the global circulation of by-products for recovery and recycling.

Thus, the content analysis of collected discourses shows a plural definition of territory in IE: while some actors focus on the integration logic within an industrial platform and consider the eco-site as the core of the definition of territory in IE, others emphasize the metropolitan vocation of an IE's territory organized and connected around different poles. Finally, some outline a territory project around cells, clusters, and sites that contribute to territorializing IE by the material and immaterial interactions they foster. Territory in IE is defined and structured in a variety of "space combinations" (Di Méo, 2008) defined by the actors through the prism of predefined explicative territorial patterns. The metropolitan territory in IE project opens a wide range of possibilities. However, discourses rarely focus exclusively on one territorial pattern: "it is multi-scale", "it is a melting pot of the three [patterns]". Collected discourses manifest a gradual evolution of the territorialization of IE, in which the three territorial patterns can be different steps:

"I feel that there is a desire among the majority of stakeholders to tend towards an eco-region, probably through the development of an eco-network on port issue etc. "And beyond:" But the next step is the metropolis, it is an eco-region."

However, this evolution does not suppose the replacing of one territorial pattern by another. The different territorial patterns coexist and endure over time, contributing to the global territorialization of the IE project:

"Currently, we are here [eco-site] with a contribution here [ecoregion]. That is to say that what we will do there [at the scale of ecosite] aims to fulfill a goal that is rather shared with other projects too, with the metropolis."

These results support the hypothesis of a "territorial mosaic" (Forman, 1995), a complex nesting of territories in IE in the Aix-Marseille-Provence metropolitan area. In definitve, the territory, through IE, is thus an effect of never complete but always becoming material and non-material networking relations (Painter, 2008). In order to summarize all of these representations and organizations of the metropolitan area in territories, we propose a cartographic representation of the territorial projections of interviewed actors' vision of the IE territories in the Aix-Marseille-Provence metropolitan area (Fig. 3).

\subsubsection{Territorial interfaces in IE}

The territorial construction process at work in IE over this geographic area outlines various spatial patterns that we assimilate, by translation from the analogy with biological systems, as biotopes. By "biotope", we understand a homogeneous spatial unit bringing together 

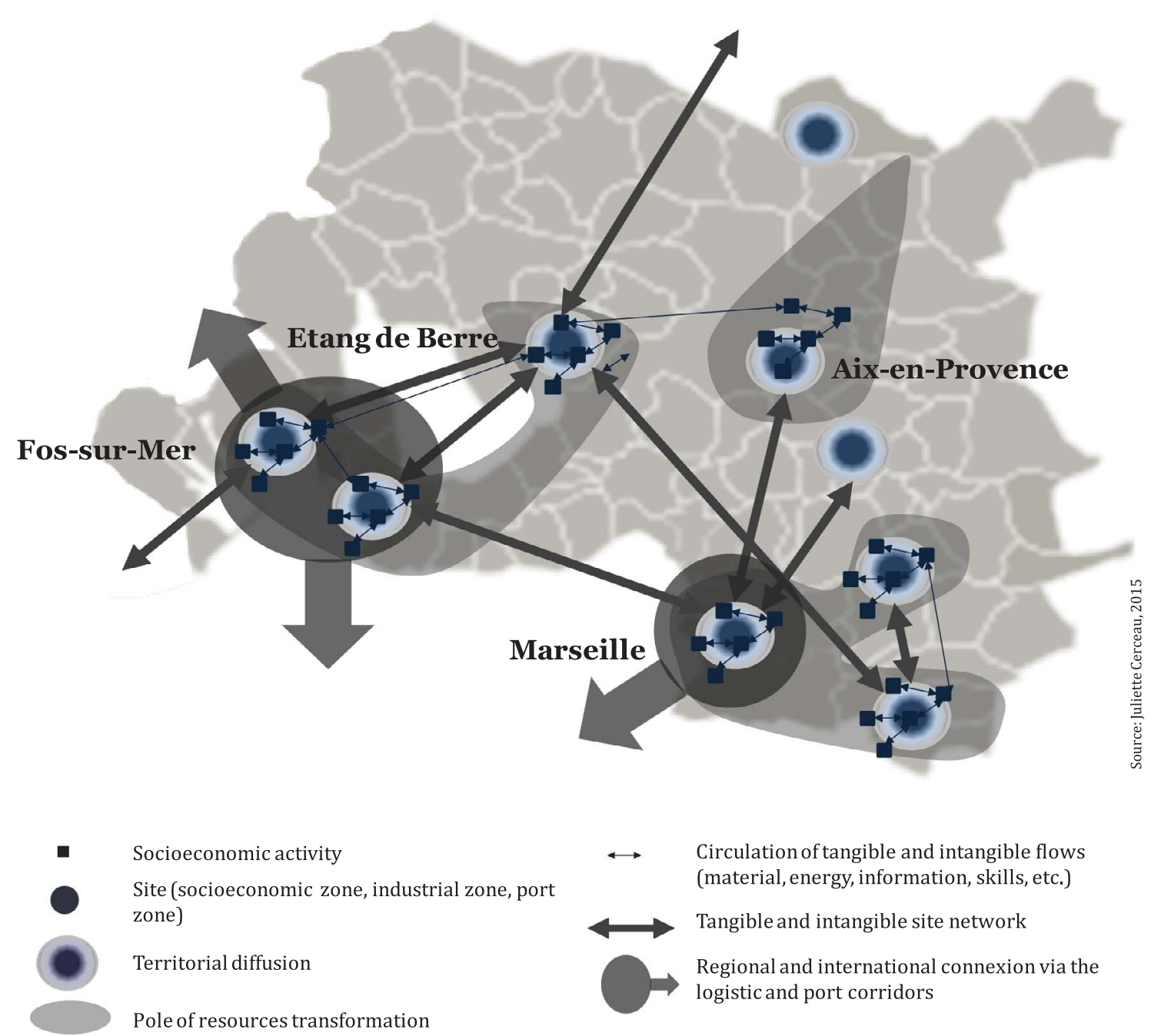

Fig. 3. Cartographic representation of the IE territorial mosaic in the Aix-Marseille-Provence metropolitan area.

an ecosystem of actors around a common definition of the territory in IE. Beyond this juxtaposition of territorial configurations, we now want to demonstrate the existence of a link between the types of actors and the types of territorial configurations. In line with Di Meo and Buleon (2005), we demonstrate that territory in IE is a "complex interweaving of relationships between social groups and spaces." The same geographic area can accommodate different meanings and aims for different social groups.

Based on the analysis of the territorial definitions given by interviewed actors, we crossed the territorial patterns of IE with the type of actors and their degree of belonging and implication in the territory (Tables 8 and 9).

As a result, we summarize this diversity of territorial patterns in three major modalities of territorialization of IE in the metropolitan area that are shared by $2 / 3$ of our panel:

- The local integrated socioeconomic platform (eco-site): the project of IE is polarized on sites characterized by the proximity between firms, the density of interactions and the integration of infrastructure and facilities. This territorial definition of IE is shared by industrial stakeholders and representatives of local authorities, mainly port authorities. It is appropriated by local stakeholders whose territorial involvement and attachment are defined with regard to their organizations' strategies.

- A multi-polar and multi-scale region (eco-region): the project of IE overlaps with the representation that actors have of the metropolitan area, with the different poles and different scales of development and innovation. Cohesion and unity has to be found through a common territorial strategy. This definition is a prerogative of network actors and regional authorities. It includes most of the missionary actors, strongly attached to and invested in their territory.

- The multiplication of exemplary eco-sites that diffuse IE principles at metropolitan and regional level (eco-site/eco-region): the IE project territorializes through the successive radiation and diffusion of best practices implemented at eco-site levels across a larger area. The multiplication of local eco-sites located in different poles and at different territorial levels is intended to foster and encourage the metropolitan and regional circularity as a dynamic pattern for flows management. This territorialization process includes the enlargement of the governance of eco-sites; first driven by industrial actors, they gradually integrate other local actors. This territorial approach of IE is mainly defended by actors representing local and regional authorities, with varying degrees of attachment to and investment in the Aix-Marseille-Provence geographic area.

Analysis of the positioning of local actors among the different territorial patterns at work in IE in the Aix-Marseille-Provence metropolitan area (Fig. 4) identified territorial interfaces where several types of actors focus their project of the territorialization of IE. For instance, the "eco-site" territorial pattern, whether considered alone or in interactions with other territorial patterns was mentioned by $65 \%$ of 
Table 8

Territorial definitions at work in IE: extract of discourses.

\begin{tabular}{|c|c|}
\hline & Examples of collected discourses \\
\hline \multirow[t]{3}{*}{ Eco-site } & "the core of IE is located at the site level" \\
\hline & "we are really based on a site approach" \\
\hline & "projects that were successful, that demonstrated their relevance, are projects that started at a local scale" \\
\hline \multirow[t]{2}{*}{ Eco-region } & "the metropolitan scale appears as a good scale" \\
\hline & $\begin{array}{l}\text { "for us, it is obvious. The project, it is here, at the eco-region scale, through the interactions between sectors [...]. It is our objective, to reach } \\
\text { coherence at a territorial scale" }\end{array}$ \\
\hline \multirow[t]{2}{*}{ Eco-network } & "we think of industries in Marseille through this network dimension" \\
\hline & "it is really relevant in terms of optimization of local networks" \\
\hline Eco-site/Eco-network & "it means starting with 7 pilot sites $[\ldots]$ and then starting to create interactions, when possible, between these 7 sites" \\
\hline Eco-site/Eco-region & $\begin{array}{l}\text { "the sites, around the Etang de Berre, it is these areas that are relevant in terms of IE"/"but the following step, it is the metropolis" } \\
\text { "it is purely local"/"it contributes to the regional anchorage of economic activities" } \\
\text { "amplify demonstration", "broaden circularity" }\end{array}$ \\
\hline Eco-network/Eco-region & $\begin{array}{l}\text { "for me, the metropolis is the real experimentation level"/"we are more for little experiments that multiply and interact, and may have sense } \\
\text { for collectivities, in habitants" }\end{array}$ \\
\hline \multirow[t]{2}{*}{ Eco-site/Eco-region/Eco-network } & "we must launch the three approaches: site, region, network" \\
\hline & $\begin{array}{l}\text { "what I find interesting about this Etang de Berre scale, is that we are on a local scale, but not micro local... It is the industrial part of the } \\
\text { metropolis"/"it contributes to the development, at a regional scale"/"we should grid these sites" }\end{array}$ \\
\hline
\end{tabular}

our sample. Business parks, industrial areas and industrial and port areas appear destined to be the focus of strong interactions between the different local actors.

While in ecology the biotope is mostly the place where interaction between species occur, the habitat provides limited resources and the sharing of these resources can result in interspecific competition (Frontier et al., 2004). Analogically with biological systems, we can make the translation that the eco-site harbors several actors who have a need for the same limited amount of resources, which enables the operational and organizational implementation of IE. For the territorialization of IE projects, cooperative or competitive strategies must be found and discussed among stakeholders in order to share effectively the limited technical, financial, and organizational resources available.

\section{Conclusion}

As a conclusion, IE appeared as quite emblematic to highlight issues and potentialities of taking into account the territorial embeddedness of resource management. Taking IE as a specific resource management approach, we were brought to question the different aspects of the connection between people and geographical places in a natural management context. Beyond the question of relevant system boundaries for resource optimization, we have addressed the territorialization processes that contributes to create new representations and new practices of space through local community-based collaborative partnerships.

This emergence of territory in IE blurs frontiers and addresses fundamental issues to question the territorial embeddedness of resource management. Philosophically, it blurs the frontiers between determinism and non-determinism, questioning the opportunities that emerge at the interstice between the natural constraints determining human activities and the capacity of human beings to choose among opportunities. Epistemologically, it revives the debate on the interest and legitimacy of the translation of ecological principles toward social behaviors, blurring the frontiers between human and non-human strategies. Concretely, it blurs the administrative frontiers by defining and building new territories emerging from a network of material and immaterial interactions between and among actors and spaces. It thus put territorial continuity and proximity in the light of territorial solidarity contributing to refine the definition of a territory in resource management context.

The new patterns of resource management fostered by IE implementation definitely contribute to the creation of new territories. This article is in line with the action research movement that promotes collective critical awareness to shed light on the fundamental processes underlying the implementation of a collective process of change (Grundy, 1988). This approach revolves around the triptych; theory, clarification and action (Berg, 2004). Indeed, from a conceptual framework addressing IE as the territory construction process, we define a methodology to highlight the different modalities of territory in IE. From this clarification, we contribute to the emergence, within a specific geographic area, of a territorial project giving meanings and orientations to collective action in terms of the territorialization of IE. Bringing out this territorial process at work in IE, we participate, along

Table 9

Territorial patterns of IE, types of actors as stakeholders and inhabitants.

\begin{tabular}{|c|c|c|c|c|c|c|c|c|}
\hline & Eco-site & Eco-region & Eco-network & $\begin{array}{l}\text { Eco-site/Eco- } \\
\text { network }\end{array}$ & $\begin{array}{l}\text { Eco-site/Eco- } \\
\text { region }\end{array}$ & $\begin{array}{l}\text { Eco-network/Eco- } \\
\text { region }\end{array}$ & $\begin{array}{l}\text { Eco-site/Eco-region/Eco- } \\
\text { network }\end{array}$ & Total \\
\hline Research actor & & 1 & 3 & 1 & 2 & & & 7 \\
\hline Network actor & & 9 & & & 3 & & 1 & 13 \\
\hline $\begin{array}{l}\text { Port, local, departmental, regional } \\
\quad \text { authority }\end{array}$ & 4 & 1 & 2 & 1 & 7 & & 4 & 19 \\
\hline Firm & 4 & 1 & & 4 & 1 & 1 & 1 & 12 \\
\hline Total & 8 & 12 & 5 & 6 & 13 & 1 & 6 & 51 \\
\hline External pathfinder & & 2 & & 2 & 2 & & & 6 \\
\hline Intervenor in transit & 1 & 1 & 2 & 1 & 2 & & & 7 \\
\hline Local stakeholder & 5 & & & 1 & 3 & & & 9 \\
\hline Local missionary & 1 & 8 & 2 & 2 & 2 & 1 & 4 & 20 \\
\hline No answer & 1 & 1 & 1 & & 4 & & 2 & 9 \\
\hline Total & 8 & 12 & 5 & 6 & 13 & 1 & 6 & 51 \\
\hline
\end{tabular}



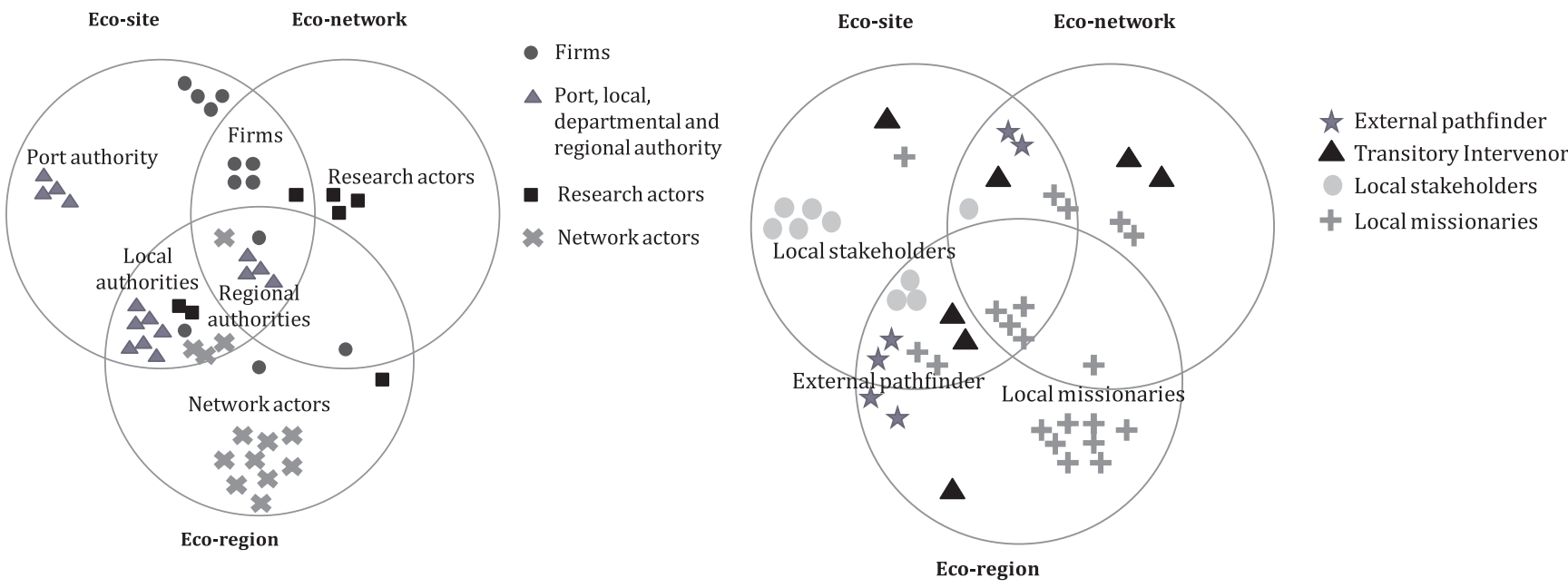

Fig. 4. Positioning of local actors among the different territorial patterns at work in IE in the Aix-Marseille-Provence metropolitan area.

with local actors, in "making a territory", bringing together the necessary conditions for the implementation of collective project resource management. We contribute to the "capacity building" of actors (Sen, 2002), understood as their ability to perform as a territory (Buclet, 2011).

\section{Acknowledgment}

Most of the research that led to this paper was supported by the French Environmental Agency ADEME, the Provence Alpes Côtes d'Azur region, the Interministerial Mission of Prefiguration for the Future Aix-Marseille-Provence Metropolis, Engie and Armines. The authors wish to thank specifically Anne-Marie Fruteau Delaclos, Christelle Deblais, Frédéric Dagnet, Vincent Fouchier, Cyril Madar, and Michel Estève for their support and contribution to this work. The authors are also very grateful to all the local stakeholders that participated in the two interview campaigns carried out in the Aix-MarseilleProvence Metropolitan area from 2013 to 2015. Guillaume Junqua is a member of ELSA, the research group for Environmental Life cycle \& Sustainability Assessment (www.ELSA-lca.org); the authors thank all the other ELSA members for their precious advice. Finally, as the preliminary research work that led to this paper was conducted during Juliette Cerceau's PhD thesis, the authors wish to thank all the members of the jury for their insightful comments on earlier drafts: Sabines Barles, Nicolas Buclet, Véronique Bellon-Maurel, César Ducruet, Gérald Hess, Catherine Gonzalez, Valérie Laforest and Miguel Lopez-Ferber. Finally, we are grateful to Adam Lindsey-Clark for his proof reading.

\section{References}

Allais, R., Reyes, T., Roucoules, L., 2015. Inclusion of territorial resources in the product development process. J. Cleaner Prod. 94, 187-197.

Allen, J., Cochrane, A., 2007. Beyond the territorial fix; regional assemblages, politics and power. Regional Studies 41 (9), 1161-1775.

Allenby, B.R., 1992. Design for Environment: Implementing Industrial Ecology. Thèse de doctorat. University of New Jersey, New Brunswick.

Ashton, W.S., Bain, A.C., 2012. Assessing the "short mental distance"in eco-industrial networks. J. Ind. Ecol. 16 (1), 70-82.

Antonsich, M., 2010. Rethinking territory. Prog. Hum. Geogr. 35 (3), 422-425.

Arefi, M., 1999. Non-place and placelessness as narratives of loss: rethinking the notion of place. J. Urban Des. 4 (2), 179-193.

Beaurain, C., Brullot, S., 2011. L'écologie industrielle comme processus de développement territorial: une lecture par la proximité. Revue d'économie régionale et urbaine 2, 313-340.

Baas, L., Boons, F., 2004. An industrial ecology project in practice; exploring the boundaries of decision-making levels in regional industrial systems. J. Cleaner Prod. 12 (8-10), 1073-1085.

Bassett, T.J., Gautier, D., 2014. Regulation by territorialization: the political ecology of conservation and development territories. Echogéo 29.

Baumann, H., 2009. Don't fence me in. In: Boons, F., Howard-Grenville, J. (Eds.), The
Social Embeddedness of Industrial Ecology. Edward Elgar Publishing, Northampton (MA).

Berg, B.L., 2004. Qualitative Reserach Methods for the Soocial Sciences. 5ème éd. Pearson Education, Inc.

Bergmann, L., Holmberg, M., 2016. Land in motion. Ann. Am. Assoc. Geograph. 4452 (April), 1-25.

Berque, A. 2000. Médiance, de milieux en paysages. 2ème éd. Editions Belin, Paris.

Berque, A., 2010. L'homme entre libre arbitre et déterminisme: sommes-nous déterminés par la géographie? 2 et 3 septembre 2010. Université des CCI, Paris.

Bey, C., 2001. Sustainable Production, Allocation and Consumption: Creating SteadyState Economic Structures in Industrial Ecology. Thèse de Doctorat. Université d'Edimbourg, Edimbourg.

Bey, C., 2005. Human systems in terms of natural systems? Employing non-equilibrium thermodynamics for evaluating industrial ecology's 'ecosystem metaphor'. Int. J. Sustain. Dev. 8 (3), 189-205.

Boons, F., 2009. Ecology in the social sciences: an overview. In: Boons, F., HowardGrenville, J. (Eds.), The Social Embeddedness of Industrial Ecology. Edward Elgar Publishing, Northampton (MA).

Boons, F., Baas, L.W., 1997. Types of industrial ecology: the problem of coordination. J. Cleaner Prod. 30 (149), 173-191.

Boons, F., Howard-Grenville, J., 2009. The Social Embeddedness of Industrial Ecology. Edward Elgar Publishing, Northampton (MA).

Bourg, D., 2001. Le nouvel âge de l'écologie. Le Débat (113), 92-105.

Bringezu, Moriguchi, Y., 2002. Material flow analysis. In: Robert, V., Ayres, L.W.A. (Eds.), A Handbook of Industrial Ecology. Edward Elger Publishing, Cheltenham, UK.

Brunner, P.H., Rechberger, H., 2003. Practical Handbook of Material Flow Analysis. CRC Press LLC, Boca Raton, Florida, pp. 336.

Brullot, S., 2009. Mise en oeuvre de projets territoriaux d'écologie industrielle en France: vers un outil méthodologique d'aide à la décision. Thèse de doctorat. Université de Technologie de Troyes, Troyes.

Brullot, S., Payen, A., Harpet, C., 2012. L'écologie industrielle et territoriale: des représentations à l'action. Colloque Association de Science Régionale de la Langue Française, 9-11 juillet 2012, Belfort.

Brullot, S., Maillefert, M., Joubert, J., 2014. Stratégies d'acteurs et gouvernance des démarches d'écologie industrielle et territoriale. Developpement durable et territoires 5 (1).

Buclet, N., 2011. Ecologie industrielle et territoriale, stratégies locales pour un développement durable. Septentrion Presses Universitaires, Villeneuve d'Ascq.

Callon, M., Lascoumes, P., Barthe Y., 2001. Agir dans un monde incertain. Essai sur la démocratie technique. Le Seuil, Collection «La couleur des idées », Paris.

Cerceau, J., Junqua, G., Gonzalez, C., Lopez-Ferber, M., Mat, N., 2012, "Industrial ecology and the building of territorial knowledge: DEPART, a French Research Action Program implemented in Harbor territories". In: Procedia - Social and Behavioral Sciences, vol. 40, pp. 622-630.

Cerceau, J., Mat, N., Junqua, G., Lin, L., Laforest, V., Gonzalez, C., 2014. Implementing industrial ecology in port cities: international overview of case studies and cross-case analysis. J. Cleaner Prod. 74 (1), 1-16.

Cheng, A.S., Kruger, L.E., Daniels, S.E., 2003. Place as an integrating concept in natural resource politics: propositions for a social science research agenda. Soc. Nat. Resour. $16,87-104$.

Chertow, M.R., 2000. Industrial symbiosis. Literature and taxonomy. Annu. Rev. Energy Environ. 25, 313-337.

Corning, P.A., 2002. The re-emergence of "emergence": a venerable concept in search of a theory. Complexity 7 (6), 18-30.

Cousin, J., 2017. Volume control: stormwater and the politics of urban metabolism. Geoforum 85, 368-380.

Cousins, J., Newell, J.P., 2015. A political-industrial ecology of water supply infrastructure for Los Angeles. Geoforum 58, 38-50.

Debarbieux, B., 2009. Territoire-Territorialité-Territorialisation: aujourd'hui encore, et bien moins que demain. In: Vanier, M. (Coord.), 2009. Territoires, territorialité, 
territorialisation. Controverses et perspectives. Presses Universitaires de Rennes, Rennes.

De Certeau, M., 1990. L'invention du quotieien; 1. Arts de faire. Gallimard, Paris.

Di Méo, G., Buléon, P., 2005. L'espace social. Lecture géographique des sociétés. Armand Colin, Paris.

Di Méo, G., 2008. Une géographie sociale entre représentations et action. Montagnes méditerranéennes et développement territorial 23, 13-21.

Ehrenfeld, J.R., 2000. Industrial ecology: paradigm shift or normal science ? Am. Behavioral Sci. 44 (2), 229-244.

Ehrenfeld, J., 2003. Putting a spotlight on metaphors and analogies in industrial ecology. J. Ind. Ecol. 7 (1), 1-4.

Erhenfeld, J.R., 2004. Industrial ecology: a new field or only a metaphor? J. Cleaner Prod. $12,825-831$.

Elden, S., 2007. Gouvernmentality, caculation, territory. Environment and planning. D; Society Space 25, 562-580.

Elden, S., 2010. Land, terrain, territory. Prog. Hum. Geogr. 34 (6), 799-817.

Erkman, S., 2004. Vers une écologie industrielle. 2ème éd., Edition Charles Léopold Mayer, Paris.

Eurostat, 2001, Economy-wide Material Flow Accounts and Derived Indicators. A Methodological Guide, Statistical Office of the European Union, Luxembourg.

Faure, A., 2012. Territoire. In: Casillo, I., Barbier, R., Blondiaux, L., Chateauraynaud, F., Fourniau, J.-M., Lefebvre, R., Neveu, C., et Salles, D., (Eds.), Dictionnaire critique et interdisciplinaire de la participation, GIS Democratie et participation, p. 2.

Filleron, J.-C., Viala, L., Milieu, géographie. Encyclopeadia Universalis, Disponible en ligne. URL: < http://www.universalis-edu.com/encyclopedi/milieu/ > Consulté le 15 avril 2013.

Finneveden, G., Moberg, A., 2005. Environmental system analysis tools, an overview. J. Cleaner Prod. 13, 1165-1173.

Forman, R.T.T., 1995. Land Mosaics. The Ecology of Landscape and Regions. Cambridge University Press, Cambridge.

Freeman, R.E., 1984. Strategic Management, a Stakeholder Approach. Cambridge University Press, Cambridge.

Frontier, S., Pichod-Viale, D., Leprêtre, A., Davoult, D., Luczak, C., 2004. Ecosystèmes. Structure, fonctionnement, évolution. 3ème éd., Dunod, Paris.

Frosch, R., Gallopoulos, N., 1989. Strategies for manufacturing. Sci. Am. 189 (3), 152.

Gibbs, D., Deutz, P., 2005. Implementing industrial ecology? Planning for eco-industrial parks in the USA. Geoforum 36 (4), 452-464.

Golubiewski, N., 2012. Is there a metabolism of an urban ecosystem? An ecological critique. AMBIO 41, 751-764.

Guibrunet, L., Sanzana Calvet, M., Castán Broto, V., 2017. Flows, system boundaries and the politics of urban metabolism: waste management in Mexico City and Santiago de Chile. Geoforum 85, 353-367.

Grundy, S., 1988. Three modes of action research. In: Kemmis, S., Taggerts, R. (Eds.), The Action Research Reader. Deakin University Press, Geelong.

Haberl, H., Winiwarter, V., Andersson, K., Ayres, R.U., Boone, C., Castillo, A., Cunfer, G., Fischer-Kowalski, M., Freudenburg, W.R., Furman, E., Kaufmann, R., Krausmann, F., Langthaler, E., Lotze-Campen,H., Mirtl, M., Redman, C.L., Reenberg, A., Wardell, A., Warr, B., Zechmeister, H., 2006. From LTER to LTSER: conceptualizing the socioeconomic dimension of long-term socioecological research. Ecol. Soc. 11(2): 13. [online] URL: < http://www.ecologyandsociety.org/vol11/iss2/art13 > .

Hammer, M., Giljum, S., Bargigli, S., Hinterberger, F., 2003, Material Flow Analysis on the Regional Level: Questions, Problems, Solutions, NEDS Working Paper, n², SERI, Hamburg.

Heidegger, M., 1986. Etre et temps. Gallimard, Paris.

Hess, G., 2010. The Ecosystem: Model or Metaphor? J. Ind. Ecol. 14 (2), 270-285.

Hidalgo, M.C., Hernandez, B., 2001. Place attachment: conceptual and empirical questions. J. Environ. Psychol. 21, 273-281.

Hoyaux, A.-F., 2000. Habiter la ville et la montagne: essai de géographie phénoménologique sur les relations des habitants au Lieu, à l'Espace et au Territoire. Université Joseph Fournier, Grenoble Thèse de doctorat en géographie.

Hoyaux, A-F., 2002. Entre construction territoriale et constitution ontologique de l'habitant: introduction épistémologique aux apports de la phénoménologie au concept d'habiter. Cybergéo; European journal of Geography. Disponible en ligne. URL: < http://cybergeo.revues.org/1824 > . Consulté le 19 juin 2013.

Inddigo, 2012, Démarche d'écologie industrielle sur le territoire du « Grand Toulois ». URL: < http://www.capemm.com/fileadmin/Sites/Capemm/documents/Visuels \%20actualit\%C3\%A9/DEI\%20ppt $\% 20$ complet.pdf $>$.

Isenmann, R., 2003. Further efforts to clarify industrial ecology's hidden philosophy of nature. J. Indust. Ecol., 6(3-4).

Jensen, P.D., Basson, L., Leach, M., 2011. Reinterpreting industrial ecology. J. Ind. Ecol. 15 (5), 680-692.
Jette, D.J., Grover, L., Carol, P., 2003. A qualitative study of clinical decision making in recommending discharge placement from the acute care setting. Phys. Ther. 83 (3), $224-236$.

Kim, J., 1999. The concept of emergence. Philos. Stud. 95, 3-36.

Korhonen, J., 2001. Four ecosystem principles for an industrial ecosystem. J. Cleaner Prod. 9, 253-259.

Loiseau, E., Junqua, G., Roux, Ph., Bellon-Maurel, V., 2012. Environmental assessment of a territory: an overview of existing tools and methods. J. Environ. Manage. 112 (15), 213-225.

Maslow, A.H., 1954. Motivation and Personality. Harper, New York.

Mark, M., 2010. Sample Size and Saturation in PhD Studies Using Qualitative Interviews [63 paragraphs]. Forum Qualitative Sozialforschung/Forum: Qualitative Social Research, 11(3), Art. 8, < http://nbn-resolving.de/urn:nbn:de:0114-fqs100387 >

McManus, P., Gibbs, D., 2008. Industrial ecosystems? The use of tropes in the literature of industrial ecology and eco-industrial parks. Prog. Hum. Geogr. 32 (4), 525-540.

Miles, M.B., Huberman, A.M., 2003. Qualitative Data Analysis; An Expanded Sourcebook. 2ème éd. SAGE Publications, Londres.

Montgomery, J., 1998. Making a city: urbanity, vitality and urban design. J. Urban Des. 3 (1), 93-116.

Morse, J., 2008. Styles of collaboration in qualitative inquiry. Qual. Health Res. 18 (1), 3-4.

Newell, J.P., Vos, R.O., 2011. "Papering” over space and place: product carbon footprint modeling in the global paper industry. Ann. Assoc. Am. Geogr. 101 (4), 730-741.

Noucher, M., 2007. Coproduction de données géographiques: pourquoi, comment et avec qui ? Conditions et démarche participative pour produire des données sur le territoire. SAGEO (Spatial Analysis \& Geomatic), Clermont-Ferrrand, 20-22 juin 2007.

Ostrom, E., 2009. A general framework for analyzing sustainability of socio-ecological systems. Science 235, 419-422.

O’Rourke, D., Connelly, L., Koshland, C.P., 1996. Industrial ecology; a critical overview. Int. J. Environ. Pollut. 6 (2-3).

Paillé, P., 2004. Echantillonnage théorique. In:Mucchielli, A. (Coord.), Dictionnaire des méthodes qualitatives. 2ème éd. Armand Colin, Paris.

Painter, J., 2008. Rethinking territory. Antipode, Radical J. Geogr. 42 (5), 1090-1118.

Panyathanakun, V., Tantayanon, S., Tingsabadh, C., Charmonduseit, K., 2012. Preliminary study on the community-based-eco-industrial estate development of Northern Region Industrial Estate, Thailand. In: Procedia - Social and Behavioral Sciences, vol. 40, pp. 478-484.

Park, R.E., 1936. Human ecology. Am. J. Sociol. 142 (1), 1-15.

Raffestin, C., 1989. Théorie du réel et géographicité. Espaces-Temps 40-41, 26-31.

Rassmussen, M.B., Lund, C., 2018. Reconfiguring frontier spaces: the territorialization of resource control. World Dev. 101, 388-399.

Redman, C.L., Grove, J.M., Kuby, L.H., 2004. Integrating social science into the long-term ecological research (LTER) network: social dimensions of ecological change and ecological dimensions of social change. Ecosystems 7, 161-171.

Rossi, J.-P., Crombe, P., Lecuyer, R., Pêcheux, M.-G., Tourette, C., 1989. La méthode expérimentale en psychologie. Bordas, Paris.

Rudolf, F., 2008. Les glissements de sens de l'écologie dans ses associations avec la ville: écologie urbaine, ville écologique et ville durable. In: Hamman, P., (Ed.), Penser le développement durable urbain: regards croisés. L'Harmattan, Paris.

Ruwet, J.-C., 2013. Territoire, éthologie. Encyclopedia Universalis. URL: < http://www. universalis-edu.com/encyclopedi/territoire/ $>$.

Schlachli P. (coord.), Rapport Comethe pour l'ANR, programme PRECODD.

Schwach, V., 1998. Avant-propos. In: Moles et Rohmer, (Ed.), Psychosociologie de l'espace. L'Harmattan, Paris.

Sen, A., 2002. Ethique et économie. 2ème éd. Presses Universitaires de France, Paris.

Spiegelman, J., 2003. Beyond the food web connections to a deeper industrial ecology. J. Ind. Ecol. 7 (1), 17-23.

Sofies, 2011. Métabolisme territorial de l'Estuaire de la Seine. Analyse des ressources en lien avec la stratégie territoriale. URL: < http://www.ecologieindustrielleestuaire.fr/ wp-content/uploads/2013/04/1-Ecologie-industrielle-Estuaire_Metabolisme_ territorial.pdf $>$

Udo de Haes, H., van der Voet, E., Kleijn, R., 1997. Substance flow analysis (SFA): an analytical tool for integrated chain management. In: Bringezu, S., Fisher-Kowalski, M., Kleijn, R., Palm, V., (Eds.), Regional and National Material Flow Accounting: From Paradigm to Sustainability. ConAccount Workshop, Leiden, The Netherlands, pp. $32-42$.

Van der Voet, E., Oers, L., Guinée, J.B., Haes, H.A.U., 1999. Using SFA indicators to support environmental policy. Environ. Sci. Pollut. Res. 6, 49-58.

Ujang, N., Zakaniya, K., 2015. The notion of place, place meaning and identity in urban regeneration. Proc. - Soc. Behav. Sci. 170, 709-717.

Vattimo, G., 1985. Introductionà Heidegger. Edition Le Cerf, Paris. 